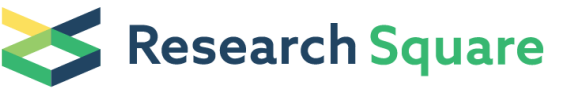 \\ Preprints are preliminary reports that have not undergone peer review. \\ They should not be considered conclusive, used to inform clinical practice, or referenced by the media as validated information.
}

\section{Study the Effects of COVID-19 in Punjab, Pakistan using Space-time Scan Statistic for Policy Measures in Regional Agriculture and Food Supply Chain}

\section{Sajjad Hussain ( $\square$ sajjad7403@gmail.com )}

COMSATS University Islamabad https://orcid.org/0000-0002-6224-9050

\section{Muhammad Mubeen}

COMSATS University Islamabad

\section{Ashfaq Ahmad}

University of Agriculture Faisalabad

\section{Shah Fahad}

University of Haripur

\section{Wajid Nasim}

Islamia University of Bahawalpur: The Islamia University of Bahawalpur Pakistan

\section{Hafiz Mohkum Hammad}

COMSATS University Islamabad

\section{Ghulam Mustafa Shah}

COMSATS University Islamabad

Behzad Murtaza

COMSATS University Islamabad

Muhammad Tahir

COMSATS University Islamabad

\section{Saima Parveen}

Institute of Southern Punjab

\section{Research Article}

Keywords: COVID-19, food security, STSS, Agriculture, Farmers' perception

Posted Date: September 8th, 2021

DOI: https://doi.org/10.21203/rs.3.rs-814098/v1

License: (c) (i) This work is licensed under a Creative Commons Attribution 4.0 International License.

Read Full License 


\section{Abstract}

Food service and retailing sectors play a vital role in economics of Punjab, Pakistan. Pakistan is included in top 50 countries which are estimated to face serious agriculture and food deficiency related challenges due to the world-wide pandemic coronavirus 2019 (COVID-19). The aim of this study was to study the effects of COVID-19 on food security and agriculture in Punjab, Pakistan using space-time scan statistic (STSS). A survey was conducted at 720 points in different districts of the province. The STSS detected "active" and emerging clusters that are current at the end of our study aera - particularly 17 clusters were formed while adding the updated case data. ArcGIS 10.3 software was used to find relative risk (RR) values; the maximum RR value was found to be 42.19 and maximum observed cases 53265 during June 15th - July 1st. Due to the highest number of cases of COVID-19 and RR vales during July, mostly farmers faced many difficulties during the cultivation of cotton and rice. Mostly farmers (72\%) observed increase in prices of inputs (fertilizers and pesticides) during lockdown. The timely results (attained through STSS and RR) can inform decision makers and public health officials about where to improve the allocation of resources (including those for farming community), also, where to apply stricter quarantines and travel bans. If the supply chain of agriculture related inputs is disturbed, farmers may find it quite difficult to access markets, which could result in a decline in production and sales of crops and livestock in study area. It is suggested that to protection of food security and to decrease the effect of the lockdown, Punjab government needs to review food policy as well as analyze how market forces will respond to the imbalanced storage facilities and capacity, supply and demand, and price control of products. The findings of this study can also help policy-makers to formulate an effective food security and agriculture adaptation strategy.

\section{Introduction}

According to Food and Agriculture Organization (FAO), agriculture contributes about one-third of worldwide gross domestic product, while 60 percent people depend on agriculture for their livelihoods in the whole world (FAO 2015). Agriculture is a very essential sector, providing food to the rapidly increasing population in Punjab, the major agricultural province of Pakistan (Siddiqui et al. 2012; Sabagh et al. 2020). Agriculture can play a significant role in economic growth (Zahoor et al. 2019; Hussain et al. 2020a; Mubeen et al. 2021). More than 60 \% people in Punjab are directly or indirectly connected with agriculture for their income. There are four major crops; wheat, rice, cotton and sugarcane in Punjab (Abbas et al. 2009; Ahmad et al. 2020; Jamal 2020; Stephens et al. 2020; Hussain and Karuppannan, 2021).

Coronavirus 2019 (COVID-19) disease is one of the most serious diseases (being contagious in nature) which is newly exposed and spread across China in December 2019; it has got global significance. As the COVID-19 pandemic prevailed during 2020, resilience of food supply chains has got significant attention during lockdown (Amjath-Babu et al. 2020; Bizoza and Sibomana 2020; Deaton and Deaton 2020; WFP 2020b; Zhu et al. 2020). COVID-19 has disrupted some activities in agriculture and supply chains (Arndt 
created a big challenge for agriculture and food security (Boulos and Geraghty 2020; Chan et al. 2020; Dlamini et al. 2020; Hafiz et al. 2020; Mhlanga and Ndhlovu 2020). Farmers were unable to buy the agricultural items, markets were locked, and food supply chains were limited due to trade restrictions and sick truck drivers facing quarantines (Alvarez-Mendoza et al. 2020; Miller 2020; Wu et al. 2020). Furthermore, decreased incomes of the farmers rendered them unable to hire farm labour, which was extremely limited because joint work was banned in fields (Khan et al. 2020c; Kansiime et al. 2020). The COVID-19 has direct impacts on household income as well as future expectations thereof, as private and public businesses and workplaces are closed mainly to enforce "social distancing" (Spinelli and Pellino 2020). Employees also left their jobs due to health concerns for their families and themselves (Béné 2020; Khan et al. 2020b; Kumar et al. 2020). The COVID-19 has significant characteristics that make its harmful impacts unique for income generation and employment in comparison to the earlier income shocks for example economic crisis in 2008 (Boughton et al. 2020; Kreutz et al. 2020; Niles et al. 2020; Richards and Rickard 2020; Siche 2020; Wu et al. 2020).

Space-time scan statistic (STSS) is a new technique to detect the "active" and emerging clusters of various diseases, which can be utilized for observation during an on-going epidemic. The STSS can identify groups that are "active" in each location; but as more information (like confirmed cases) becomes presented, STSS can be repeated to confirm the occurrence as well as track the clusters in space and time, update relative risks (RR) for every area effected due to disease, and detect new emerging clusters (Desjardins et al. 2020). The important purpose of using a STSS (rather than reflective) is to only focus on significant clustering that is "active" or current at the time of the analysis; which contempt clusters that may have occurred as well as are no longer a public health threat. The STSS has been used to detect emerging clusters of shigellosis, measles, thyroid cancer, and syndromic observation (Yih et al., 2010).

Geographic Information Systems (GIS) has been applied to the field of agriculture in various domains including land management, regional agricultural resource information and planning (Zhang and Cao 2019), management of grain distribution and decision-making related to food production, research in the areas of agricultural production potential and crop yield estimation (Hussain et al. 2020b; Ali et al. 2019; Khan et al. 2020d). In the fight against COVID-19, GIS has played a significant role in different aspects, for example tracking of confirmed cases of COVID-19, rapid visualization of COVID data and combination of multi-source big data (Sun et al. 2020; Zhou et al. 2020). In general, GIS (along with spatial analysis) could be important tool for information, treatment and prevention of different diseases (Rezaei et al. 2020). The GIS tools could be used as an imagining help to map the spatial spreading of the various diseases, the resources available and risk factors for prevention and treatment (Zhang et al. 2020). The GIS has matured and developed relatively quickly as well as has a complete technical route for preparation and modelling of the data, platform creation, and map production (Arab-Mazar et al. 2020; Lakhani 2020).

The farmers are playing an important role in sustainability of food security and agriculture in Punjab Loading [MathJax]/jax/output/CommonHTML/jax.js ing raw material for exports, yet they are facing a great deal 
of challenges (Harris et al. 2020; Manzoor et al. 2019). Different reports show that the non-availability of labour may disturb some harvesting activities, mostly in Pakistan where wheat and pulses are to be harvested in the month of April (Ali and Rahut 2020; Khan et al. 2020a; Pervaiz et al. 2019). In Punjab, cultivated area decreased along with farmers' incomes during lockdown because of COVID-19 (WHO 2020). Agriculture is fundamental to Punjab's economy, contributing over $19 \%$ of GDP of Pakistan and paying about $39 \%$ of the labor force (PBS 2020). Fruit and Vegetable growers were mostly effected because they could not sell their produce due to market closings and limited movement of goods (Khaliq et al. 2020). So, Punjab needs to be prepared for potential surge about agriculture in upcoming months. Here we focused on food security of post-COVID-19 as well as agriculture supply chain management of grains, pulses, fruits, and vegetables, impacted by lockdown. The aims of this research were to:

1. Analyze the trend and relative risk (RR) in the spread of COVID-19 by using STSS.

2. Study the impacts of COVID-19 on agriculture in Punjab (Pakistan).

3. Assess the effects of COVID-19 for food supply chains.

\section{Materials And Methods}

\subsection{Study location}

The study location was composed of Punjab province (Pakistan) shown in Fig. 1. Punjab is the greatest populated province of Pakistan, with a population of about 110 million in 2017. Punjab is the 2nd biggest province by area (with an area of 205,344 square kilometres) after Balochistan province. It is bounded by Khyber Pakhtunkhwa province to the west, the Balochistan province to the southwest, Sindh province to the south, as well as the Azad Kashmir and Islamabad Capital in the north. Punjab province is also bounded by province of Rajasthan and Indian Punjab to the east as well as Jammu and Kashmir in the north. Lahore is capital as well as largest city of Punjab which has been the historical capital of Punjab province. Punjab land contains generally fertile alluvial plains of the Indus River with its 4 main tributaries in Pakistan, the Sutlej, Ravi, Jhelum, and Chenab rivers. Punjab has 4 cropping zones for example: (i) mixwheat, (ii) rice-wheat, (iii) cotton-wheat and (iv) rainfed. The detailed pictorial view of different cropping zones in different regions of the province is shown in Fig. 1.

\subsection{Data collection and analysis}

This research is primarily based on the survey which was conducted from farmers all over the province of Punjab (Pakistan). A survey was conducted at 720 points in different districts of Punjab; so the study results are based on this survey and are also based on some data from different websites, newspapers, agriculture department and Pakistan Bureau of Statistics (PBS) who conducted different surveys in Pakistan. The survey was conducted via a web form, which was available on PC/desktop and mobile phone. The information collection duration was inclusive of April to August, 2020. The survey was dispersed usually through face to face, via email, and by communication channels and social media; the 
Ministries of Agriculture. Respondents were imagined live on a communicating dashboard as well as regularly observed to confirm their validity on the basis of cross referencing with previous knowledge and secondary data (AYRA 2020). Data were noted on the survey data sheet i.e., longitude, latitude (by using GPS software through smart phone), class name, and three geo-tagged pictures at every survey location. These collected data also used independent information for accuracy and analysis by different software's. After collecting these data, data were analysed and graphs were made using Microsoft word and excel.

Additionally, information used in this research were patients of COVID-19 disease in Punjab, Pakistan from 15th March 2020 to 1st Jan 2021 attained from the health department of Punjab (WHO 2020).

\subsection{Space-time scan statistic (STSS)}

To detect the space-time clusters that are still occurring or "active", we utilized the prospective version of the STSS (Kulldorff, 2018; Desjardins 2020). The STSS identifies the COVID-19 that are still active (excess risk still present) in our dataset during the previous months. We also perceive space-time clusters of COVID-19 that are emerging and "disregard" clusters that do not have a statistically important excess RR (for example more detected than expected COVID-19 cases) in study area. In the other word, the STSS estimates potential clusters that are still taking place at the end of November. The (STSS) services moving cylinders that scan the Punjab for possible space-time clusters of COVID-19 cases. Next, every cylinder is extended until a maximum temporal and spatial upper bound is reached, while every cylinder is a potential cluster. We set the upper bounds to have a maximum spatial and temporal scanning window size of $10 \%$ of the population at-risk to avoid extremely large clusters; and $50 \%$ of the study duration, relatively. An unknown large number of cylinders of different spatial and temporal sizes are produced around each centroid until the maximum temporal and spatial thresholds are reached; the expected and observed case counts are computed within every cylinder, which are derived from the total number of centroids captured in each cylinder. We selected the discrete Poisson data model, where we expected that the COVID-19 cases followed a Poisson distribution according to the population of the study area. The null hypothesis $\mathrm{H}_{0}$ states that the model reflects a constant risk with an intensity $\mu$, which is proportional to the at-risk population. The alternative hypothesis $\mathrm{H}_{\mathrm{A}}$ states that observed the number of COVID-19 cases exceeds the expected number of cases derived from the null model (elevated risk within a cylinder). The number of expected COVID-19 cases $(\mu)$ under the null hypothesis $\mathrm{H}_{0}$ is resultant as shown in Eq. (1):

$$
\mu=p * \frac{C}{P}
$$

Where $p$ the population in $i ; C$ the total COVID-19 cases in the Punjab; and $P$ the over-all projected population in the study area. Note that the model assumes that the population is static for every district at any time of period. Moreover, the STSS uses various cylinder sizes, and the cylinder with the highest likelihood ratio (maximum) is the most likely cluster. To circumvent the assumption that the relative risk of COVID-19 is homogenous throughout an important space-time cluster, we also report and visualize the 
RR for every district of Punjab that belongs to a cluster. The (RR) for each location belonging to a cluster is derived from Eq. (2):

$$
R R=\frac{C / e}{(C-C) /(C-e)} \ldots \ldots \ldots \ldots
$$

Where $c$ is the overall number of COVID-19 cases in the study area, $e$ is the total number of expected cases in the study area, and $C$ is the total number of observed cases in the province of Punjab. The RR is the relative risk within a location divided by the risk outside of the location (i.e. everywhere else). The testified clusters have a RR, which is derived the same way as Eq. (2); but the clusters RR is estimated risk (observed/expected) divided by the risk outside of the cluster. The results classify statistically important emerging clusters of COVID-19 in the study area for each district from March 2020 to November 2020.

\section{Results And Discussion}

\subsection{Trend and relative risk (RR) of COVID-19}

The COVID-19 epidemic was initial described in Wuhan, China and has feast to more than 200 countries till now. In Punjab, the first case was reported by 15th March 2020 at Lahore. The novel COVID-19 has spread relatively at faster rate from March to July, and the number of reported infections was 53,265 on July 1 (the highest figure so far). The number of confirmed cases increased during the month of June and July, mostly due to people having travel histories of the affected places. On 15th July, total confirmed cases were reported to be 38786 which decreased as compare to June. At the end of July, observed COVID-19 cases decreased in different areas of the study region. The decrease in cases continued till Sep 15 , but afterwards, the disease spread at increasing rate and reached to the cases 24,552 on Dec 1 . On 15th Janwary, total confirmed cases were reported to be 17084 which decreased as compare to December and November. At the end of February, observed COVID-19 cases decreased in different areas of the study region. But during March, 2021 COVID-19 cases were also again increased as compared to last month which is called 3rd wave of COVID-19 in Punjab. On 15th March, COVID-19 cases were reported 38647, due to high no. of cases, different district has lockdown. Although, there seems to be some decline in the no. of cases after Dec 1, there are still chances the disease may upsurge (Fig. 2). In several district hospitals, nearly $90 \%$ of ventilators and oxygen beds are already occupied, while some hospitals are turning away new patients as $100 \%$ of beds allocated for coronavirus patients are already taken, according to ministry officials. Pakistan is set to receive millions of COVID-19 vaccine doses from various countries in the coming weeks to speed up its slow immunization campaign. So far, out of its population of 210 million, nearly 1.4 million people, including health professionals and people above 50 years old, have been inoculated. The lockdown is up again and have left millions of daily wage laborers, farmers etc. unemployed. The situation is getting worse with every passing hour will no space in hospitals and limited oxygen. 
Table 1 was presented the features of the statistically important emerging STSS of COVID-19 in each district of Punjab from March 2020 to November 2020. Clusters were based on the mean values of all districts of Punjab with a RR $>1$ (i.e. more detected than expected cases). Punjab has an RR of 0.049 with 63 detected cases during 1 March to 15 March in Punjab(cluster 1). Cluster 3 contains RR of 1.91 and 2,413 observed cases. Cluster 5 contains RR of 10.03 and 12,661 observed cases in the study area during May 1st - May 15th. Cluster 8 contains maximum RR values of 42.19 and maximum observed cases 53,265 during June 15th - July 1st. During this cluster, almost all the districts in Punjab contained RR $>1$. After this cluster, it is observed that RR values decreased because observed values also decreased in the study area. The cluster 10 contains RR of 9.96 and 12,674 observed cases during July 15th - Aug 1 st. In cluster 12 RR of 3.52 and 4,440 cases were observed during Aug 15th - Sep 1st. Cluster 14 contains values like (observed cases $=4,412)$ and $(R R=3.49)$ and show the decreasing tread in COVID-19 cases in study area. But in cluster 17, trend of COVID-19 showed increased as pervious trend in study area like observed cases $=13,269$ and $R R=10.51$ during Nov 1 st - Nov 15th and almost 10 districts have RR $>1$ in study area. By comparison of Table 1 and Fig. 2, it is clear that it was not always necessary that if the no. of active cases in Punjab increased, there should be higher relative risk for more no. of districts and vice versa. This can be found at clusters 4 and cluster 10. In cluster 4 (April 15 to May 1), although the no. of active cases was on increase in the whole Punjab but the no. of districts having RR $>1$ decreased as compared to cluster 3 (decreased from 5 to 3). Similarly, in cluster 10 (July 15 to Aug 1), the no. of active cases was decreasing for the study region but the districts having RR $>1$ increased from 23 (cluster 9) to 27. So, STSS provides a valuable information regarding potential of the disease spread in a given region and may be used as a useful information for timely planning of resources allocation, trade restrictions and lock down. 
Table 1

space-time scan statistic (SPSS) of COVID-19 from March to November 2020 in Punjab (RR = relative risk)

\begin{tabular}{|llllll|}
\hline Cluster & Duration & $\begin{array}{l}\text { Observed } \\
\text { cases }\end{array}$ & $\begin{array}{l}\text { Expected } \\
\text { cases }\end{array}$ & RR & Districts with RR > 1 \\
\hline 1 & Mar 1th - Mar 15th & 63 & 1.24 & 0.049 & 0 \\
\hline 2 & Mar 15th - April 1st & 810 & 16.04 & 0.64 & 1 \\
\hline 3 & April 1th - April 15th & 2413 & 47.78 & 1.91 & 5 \\
\hline 4 & April 15th - May 1st & 6916 & 136.95 & 5.48 & 3 \\
\hline 5 & May 1th - May 15th & 12661 & 250.72 & 10.03 & 9 \\
\hline 6 & May 15th - June 1st & 22417 & 443.90 & 17.75 & 21 \\
\hline 7 & June 1th - June & 44846 & 888.03 & 35.52 & 30 \\
\hline 8 & June 15th - July 1st & 53265 & 1054.75 & 42.19 & 35 \\
\hline 9 & July 1th - July 15th & 38786 & 768.05 & 30.72 & 23 \\
\hline 10 & July 15th - Aug 1st & 12574 & 249 & 9.96 & 27 \\
\hline 11 & Aug 1th - Aug 15th & 8130 & 161 & 6.44 & 19 \\
\hline 12 & Aug 15th - Sep 1st & 4440 & 87.93 & 3.52 & 14 \\
\hline 13 & Sep 1th - Sep 15th & 2887 & 57.17 & 2.29 & 15 \\
\hline 14 & Sep 15th - Oct 1st & 4412 & 87.38 & 3.49 & 12 \\
\hline 15 & Oct 1th - Oct 15th & 4604 & 91.17 & 3.64 & 8 \\
\hline 16 & Oct 15th - Nov 1st & 6060 & 120.01 & 4.8 & 7 \\
\hline 17 & Nov 1th - Nov 15th & 13269 & 262.75 & 10.51 & 10 \\
\hline & & & & & 19 \\
\hline
\end{tabular}

By STSS, COVID-19 cases pattern in 6 different classes was 0 to 5,5 to 10,10 to 15,15 to 20,20 to 30 and >30 from March, 2020 to November, 2020 (Fig. 3). These classes show the risk of exposing the spatial spread of COVID-19 in relation to various districts of Punjab, based on district population as well as environmental factors which may control the distribution of the cases. The maximum patients returning to the homeland, including friends, families, and relatives (who have been in close contact with incubation carriers), was reported on daily basis as an observational analysis. We highlight all districts, which are known as the initial main hotspots of the epidemics in the study area. District Lahore is known to have the first Punjab case of COVID-19, which was presented by current travellers in China; leading to deadly epidemics in nursing homes as well as the surrounding area. The Figure shows that district Lahore and Multan have greatest values of RR like > 30 of COVID-19 in study area. Various districts like Loading [MathJax]/jax/output/CommonHTML/jax.js Jhang, TT singh, Khanewal, Sahiwal, Okara, Pakpattan and 
Bahawalnagar indicated very less RR values of COVID-19. Areas with an RR of 0 are more transparent to focus than on the areas with an raised risk that "contribute" to the emerging clusters. Figure 3 shows that various populated districts were within an emerging cluster across the study area.

\subsection{Effects of COVID-19 on agriculture}

According to the survey, most respondents (43\%) perceived that COVID-19 affected the agriculture in study area. Only $11 \%$ expected little to some effect (Fig. 4). Approximately half anticipated that living effects would be "moderate" or "severe". The projected severity of livelihood effects was dependable across female and male respondents. Farmers involved in petty trade and everyday casual labour had the greatest negative view, with one-fourth expecting severe effects on agriculture. Most residents (57\%) observed that their health has particularly changed due to COVID-19 lockdown (Fig. 5). Similarly, almost $70 \%$ farmers had the opinion that their economic conditions are changed during these days, but the only $22 \%$ residents said that economic conditions have not changed in Pakistan (Suleri 2020). By Jamal (2020), mostly (68\%) farmers observed that agricultural yield was affected to a great extent due to lockdown during April and May. Furthermore, almost $27 \%$ of the respondents reported that agriculture yield did not change during lockdown. About $62 \%$ of the respondents responded that land holding was affected by COVID-19 (Fig. 6).

Wheat is the major crop grown in study area during the rabi season, and it is produced by almost $88 \%$ of respondents during April and May. Mostly farmers indicated that COVID-19 affected during sowing to cotton and wheat due to the highest no of cases and RR values during month of July. Almost 8 percent respondents grew maize, which is used commonly for poultry feed; almost 4 percent respondents raised vegetables and other crops. The COVID-19 had mostly affected the wheat and maize harvest. Mostly farmers ( $86 \%$ ) stated that they could complete harvesting during the last week of April and therefore had faced extremely effects due to COVID-19 as shown in Fig. 7. Almost $9 \%$ respondents reported that they had faced moderated effects on wheat and $5 \%$ faced some effects during COVID-19. The COVID-19 had also effects on vegetable as well as other crops. Similarly, $60 \%$ respondents reported that they faced extreme effects on vegetables and other crops due to COVID-19. Almost $45 \%$ of fruit and vegetable cultivators got very low prices, and $55 \%$ could not visit the markets due to COVID-19. Mostly farmers indicated that COVID-19 was the key reason of these problems. Most of the wheat and other crops harvest were spared due to COVID-19 related problems. However, milk producers were affected due of COVID-19, as dealers were unable to buy milk from the dairy forms. Mostly markets and restaurants were closed; the milk demand distorted resulting in less milk prices. The $35 \%$ of farmers stated that they were facing disruptions in receiving and purchasing fertilizer and seed from market during COVID-19.

Respondents showed facing extreme effects in the supply of the different farm inputs during COVID-19: for example, the delivery and purchase of fertilizer by $81 \%$, seed by $90 \%$; and pesticides by $86 \%$ (Fig. 8 ).

According to Jamal (2020), almost 70 percent of Pakistan's farmers depend on farm labourers, who come from the less income regions before the harvesting period. But during this season, they could not make it 
for the wheat harvesting, which in his area is set to start next week. This farmer is one of hundreds of thousands of farmers, dreadfully searching for labour for wheat harvest, mostly in Punjab and southern Sindh (the two bread-baskets for Punjab). The cultivation area for wheat has already decreased due to the changing climate and defective government policies in current years. The interruption in harvesting could decrease enormous amounts of winter crops, mainly wheat, in study area. The COVID-19 has also disturbed harvesting during this season. "Several labourers have personally told that they are scared of getting infected".

Farmers could not avail transportation for transporting fresh food to urban and local markets. Furthermore, day meal packages in schools were disturbed because food assistance could not be supplied to the schools (Sahoo and Rath 2020). Effects of COVID-19 on our agriculture as well as food system need to be informed and accelerated by practices and ideas all over the world (Goddard 2020). By work in collaboration to bring partnerships and ideas together, the world-wide community (as well as one of the greatest susceptible people in Punjab) has a much stronger chance of coping the effects of COVID19 on food security as well as defending the food production and agriculture. The lockdown disturbed food supply chains of extreme effected agricultural products for example vegetables, milk, and fruits, but it had moderately effect on the wheat and other crops harvest as well as marketing in study area. By Gray (2020), due to increase in food diffidence during lockdown, different organizations and countries are increasing special labours to keep agriculture securely running as a vital business, markets being provided in nutritious and adorable food, and customers still able to purchase and access food despite income losses and movement restrictions. Farmers must have access to markets without any discontinuation. This can be achieved if maximum government procurement and private markets work side by side. Small dairy and poultry farmers should be provided more targeted help, because the input supply and market-access problems of these businesses during pandemic are of urgent nature. Farmers and other agriculture-related workers should be involved in the government's social safety programs and support package during the COVID-19 crisis. The government should encourage trade by evading import constraints and export bans. Government can also play an important role by confirming control on price as well as food security during the COVID-19 crisis.

\subsection{Effects of COVID-19 on food supply chain}

COVID-19 has a serious threat for those who put the food on our plates; it has disturbed the complete food supply chain comprising crop producers, transporters, processors, sellers, marketers and customers. According to the survey conducted, mostly farmers ( $72 \%)$ observed an increase in food prices. However, $28 \%$ respondents perceived that food prices have not been changed during lockdown. Most people (57\%) reported that they could not access to markets and stores during lockdown. However, $43 \%$ of respondents experienced being able to have regular access to markets and grocery stores during COVID-19 (shown in Fig. 9). The main issues of limiting market access were a combination of closing of markets, movement constraints, as well as concerns about leaving the household. Their main restrictions to markets access were transport limits as well as adult members in the house being self-quarantined. 
The accessibility of food and other necessities of life were less than normal; on the other hand, very few farmers showed that vital food items were unavailable. Most respondents (47\%) perceived fresh food available during lockdown (Table 2). Fresh food seemed slightly less accessible than staple food. Hygiene and medicines were mostly available in stores and market, with $3-7 \%$ of farmers showed that these items were unavailable. Mostly farmers showed that medicines were mostly available in market, but only $3 \%$ were of the view that these were not available during lockdown. According to WFP (2020a), almost 23 percent people in drought-prone zones of world are under stress, while 51 percent people in these regions are in worse conditions or crisis. Stressed houses are "the households which have minimally adequate food consumption but are unable to afford some essential non-food expenditures without engaging in stress-coping strategies".

Table 2

Availability of items in stores in percentage during Lockdown in Punjab

\begin{tabular}{|lllll|}
\hline & Fresh food & Medicines & Hygiene & Staple food \\
\hline Available & 47 & 72 & 66 & 80 \\
\hline partially available & 42 & 25 & 23 & 15 \\
\hline Not available & 9 & 3 & 7 & 5 \\
\hline Don't know & 2 & 0 & 4 & 0 \\
\hline
\end{tabular}

In Punjab, vegetable and fruit markets were crushed by COVID-19, starting in April 2020. Due to closing of bars, schools and restaurants, crop growers and suppliers were forced to shift deliveries completely from the food services to the retail channel. COVID-19 could potentially affect the smooth function of transport at about every step along the food supply chain. COVID-19 disease could limit the obtainability of skilled employees in the transport sector in food supply chain. This supply chain contains inputs to production area to storage, to manufacturers and processors, as well as to retailers and distributors. Limitations in agricultural labours movements might increase food prices and limit their availability. The countries which consume much imported food will have to bear increased food prices due to the depreciation in their local currency value as compared to the US dollar (Imran 2020).

Before COVID-19 disease, $820 \mathrm{M}$ people were under-nourished, with two billion people facing food diffidence all over the globe (Saha et al. 2020). By Sumner et al. (2020), numerous million peoples are living dangerously nearby the poverty line: they deficiency the physical as well as economic means to obtain food due to the supply disruptions, self-isolation, lost income and movement. For instance, 30\% Pakistanis are unable to afford more than one meal a day, the country's Prime Minister has given the warning that an interruption of economic activity due to lock down will be extremely detrimental. The lockdowns by COVID-19 and its disruptions have revealed the fragility of people's access to vital services and goods (Chen et al. 2020). In food and health systems, serious inequalities and weaknesses have come to light. Food systems, the people sustaining them and public goods they distribute, have been 
due to change in climate in next few years. According to Galanakis (2020), COVID-19 has adversely impacted the food systems and supplies that must be observed. It is vital to take all essential actions to remove main barriers to procurement of food during lockdowns, while ensuring consumers and workers security. Suitable action must be taken to confirm that farm and food workers as well as travelling labourers and those in the informal area have access to safe working environments.

The COVID-19 disaster has excelled a attention on the susceptibilities of food security on 3 faces: The first one is that, industrial agriculture is creating loss of habitat and could develop conditions conducive for viruses to emerge and spread. At second place, a range of distractions are challenging the resilience of food supply chains. Thirdly, most people are living perpetually on the dangerous poverty, malnutrition and cusp of hunger and are extremely susceptible to the effects of a world-wide decline. Our results will help for the increasing the capacity of local government and farmers to implement sound strategies for improvement of food and agriculture during COVID-19. It is also an essential for the current application of policies for policy-makers on easy and adequate availability of farming evidence for the local farmers to the improvement of agriculture and food security.

\section{Conclusion}

The objective of this research was to quickly study of COVID-19 in Punjab, Pakistan; this was achieved by using STSS. Due to maximum observed cases 53265 and RR values 42.19 during June 15th - July 1st, mostly farmers faced many difficulties during the growing of cotton and rice. However, it was not necessary that by increasing the no. of active cases in the whole Punjab, the RR risk would be higher for all the districts. This was shown by clusters 4 and 10. Mostly farmers stated that wheat harvesting, as well as selling was disturbed due to the effects of the limited movement of goods forced due to the COVID-19 in Punjab. According to the survey conducted, mostly farmers (72\%) observed an increase in food prices in study area during lockdown. Accessibility of medicines, hygiene and fresh food appeared to be less than regular form in study area. Mostly people (57\%) reported that they could not access to markets and stores and almost $43 \%$ of respondents experienced being able to have regular access to markets and grocery stores during COVID-19 in study area. In conclusion, COVID-19 will have longer lasting impacts on agriculture sector and food supply chains in Punjab. Government will have to collaborate and innovate for agriculture policy and food security. This will allow best managing their agri-

food export and imports, ensure that people have access to food and decrease the risks related to food trade bans.

\section{Declarations}

Ethics approval: Not applicable

Consent to participate: I am free to contact any of the people involved in the research to seek further clarification and information. 
Consent to publish: The authors grant the journal/ publisher the sole and exclusive license of the full copyright in the contribution. Consequently, the journal/ publisher shall have the exclusive right throughout the world to publish and sell the contribution in all languages, and in any form i.e., hard copy, digital and electronic form.

Authors' contributions: Sajjad hussain, Muhammad Mubeen, and Wajid Nasim proposed the main concept and highly involved in write-up. Ashfaq Ahmad assisted in data analysis and preparation spatial map. Muhammad Amjad1, Hafiz Mohkum Hammad is involved to write-up and review. Ghulam Mustafa Shah ${ }^{1}$, Behzad Murtaza ${ }^{1}$, Muhammad Tahir ${ }^{1}$, Shah Fahad, and Saima parveen involved to review, editing, review and English grammar correction.

Funding: The authors declare that they have no known competing financial interests or personal relationships that could have appeared to influence the work reported in this paper.

Competing interests: We declare that all authors have no any potential conflict of interest including financial and personal or other relationships with other people or organizations.

Availability of data and material: The datasets used and/or analyzed during the current study are available in the article/ from the corresponding author on request.

\section{References}

1. Abbas, M., Lodhi, T. E., Aujla, K. M., \& Saadullah, S. (2009). Agricultural extension programs in Punjab, Pakistan. Pakistan Journal of Life and Social Sciences, 7(1), 1-10.

2. Ahmad, D., Afzal, M., \& Rauf, A. (2020). Environmental risks among rice farmers and factors influencing their risk perceptions and attitudes in Punjab, Pakistan. Environmental Science and Pollution Research, 1-12. https://doi.org/10.1007/s11356-020-08771-8.

3. Ali, A., \& Rahut, D. B. (2020). Localized Floods, Poverty and Food Security: Empirical Evidence from Rural Pakistan. Hydrology, 7(1), 2. https://doi.org/10.3390/hydrology7010002.

4. Ali, M., Mubeen, M., Hussain, N., Wajid, A., Farid, H.U., Awais, M., Hussain, S., Akram, W., Amin, A., Akram, R. \& Imran, M. (2019). Role of ICT in Crop Management. In Agronomic Crops (pp. 637-652). Springer, Singapore. https://doi.org/10.1007/978-981-32-9783-8_28.

5. Alvarez-Mendoza, C. I., Teodoro, A., Freitas, A., \& Fonseca, J. (2020). Spatial estimation of chronic respiratory diseases based on machine learning procedures-an approach using remote sensing data and environmental variables in quito, Ecuador. Applied Geography, 123, 102273. https://doi.org/10.1016/j.apgeog.2020.102273.

6. Amjath-Babu, T. S., Krupnik, T. J., Thilsted, S. H., \& McDonald, A. J. (2020). Key indicators for monitoring food system disruptions caused by the COVID-19 pandemic: Insights from Bangladesh towards effective response. Food Security, 12(4), 761-768. 
7. Arab-Mazar, Z., Sah, R., Rabaan, A. A., Dhama, K., \& Rodriguez-Morales, A. J. (2020). Mapping the incidence of the COVID-19 hotspot in Iran-Implications for Travellers. Travel Medicine and Infectious Disease. doi: 10.1016/j.tmaid.2020.101630.

8. Arndt, C., Davies, R., Gabriel, S., Harris, L., Makrelov, K., Robinson, S., ... \& Anderson, L. (2020). Covid19 lockdowns, income distribution, and food security: An analysis for South Africa. Global Food Security, 26, 100410.

9. AYRA, H. (2020). Food security, the farmers of Pakistan and coronavirus. Arab news March 29, 2020. https://www.arabnews.pk/node/1649496

10. Béné, C. (2020). Resilience of local food systems and links to food security-A review of some important concepts in the context of COVID-19 and other shocks. Food Security, 1-18.

11. Bizoza, A., \& Sibomana, S. (2020). Indicative Socio-Economic Impacts of the Novel Coronavirus (Covid-19) Outbreak in Eastern Africa: Case of Rwanda. Available at SSRN 3586622.

12. Boughton, D., Goeb, J., Lambrecht, I., Mather, D., \& Headey, D. D. (2020). Strengthening smallholder agriculture is essential to defend food and nutrition security and rural livelihoods in Myanmar against the COVID-19 threat: Elements for a proactive response (Vol. 2). Intl Food Policy Res Inst.

13. Boulos, M. N. K., \& Geraghty, E. M. (2020). Geographical tracking and mapping of coronavirus disease COVID-19/severe acute respiratory syndrome coronavirus 2 (SARS-CoV-2) epidemic and associated events around the world: how 21st century GIS technologies are supporting the global fight against outbreaks and epidemics. doi: 10.1186/s12942-020-00202-8.

14. Brewin, D. (2020) The impact of COVID-19 on the grains and oilseeds sector. Canadian Journal of Agricultural Economics/Revue canadienne d'agroeconomie.

15. Chan, J. F., Yuan, S., Kok, K. H., To, K. K., Chu, H., Yang, J., Xing, F., Liu, J., Yip, C. C.-Y., Poon, R.W.-S., Tsoi, H.W., Lo, S. K.-F., Chan, K.H., Poon, V. K.-M., Chan, W.-M., Ip, J.D., Cai, J.P., Cheng, V.C.-C., Chen, H., Hui, C. K.-M.\& Yuen, K. Y. (2020). A familial cluster of pneumonia associated with the 2019 novel coronavirus indicating personto-person transmission: A study of a family cluster. Lancet, 395(10223), 514-23. DOI: https://doi.org/10.1016/S0140-6736(20)30154-9.

16. Chen, Q., Liang, M., Li, Y., Guo, J., Fei, D., Wang, L., \& Wang, J. (2020). Mental health care for medical staff in China during the COVID-19 outbreak. The Lancet Psychiatry, 7(4), e15-e16.

17. Deaton, B. J., \& Deaton, B. J. (2020) Food security and Canada's agricultural system challenged by COVID-19. Canadian Journal of Agricultural Economics/Revue canadienne d'agroeconomie. https://doi.org/10.1111/cjag.12227

18. Desjardins, M. R., Hohl, A., \& Delmelle, E. M. (2020). Rapid surveillance of COVID-19 in the United States using a prospective space-time scan statistic: Detecting and evaluating emerging clusters. Applied Geography, 102202. https://doi.org/10.1016/j.apgeog.2020.102202.

19. Dev, S. M. (2020). Addressing COVID-19 impacts on agriculture, food security, and livelihoods in India. International Food Policy Research Institute (IFPRI).

20. Dlamini, W. M., Dlamini, S. N., Mabaso, S. D., \& Simelane, S. P. (2020). Spatial risk assessment of an Loading [MathJax]/jax/output/CommonHTML/jax.js : A case of COVID-19 in Eswatini. Applied Geography, 125, 
102358. https://doi.org/10.1016/j.apgeog.2020.102358.

21. FAO (2015) Climate-Smart Agriculture Source Book. The Food and Agriculture Organization of the United Nations.

22. Galanakis, C. M. (2020). The Food Systems in the Era of the Coronavirus (COVID-19) Pandemic Crisis. Foods, 9(4), 523.

23. Goddard, E. (2020) The impact of COVID-19 on food retail and food service in Canada: Preliminary assessment. Canadian Journal of Agricultural Economics/Revue canadienne d'agroeconomie.

24. Gray, R. (2020) Agriculture, transportation, and the COVID-19 crisis. Canadian Journal of Agricultural Economics/Revue canadienne d'agroeconomie.

25. Guo, Y. R., Cao, Q. D., Hong, Z. S., Tan, Y. Y., Chen, S. D., Jin, H. J., Tan, K. S., Wang, D. Y. \& Yan, Y. (2020). The origin, transmission and clinical therapies on coronavirus disease 2019 (COVID-19) outbreak - An update on the status. Military Medical Research, 7 (1), 11. DOI: https://doi.org/10.1186/s40779-020-00240-0.

26. Hafiz, H., Oei, S. Y., Ring, D. M., \& Shnitser, N. (2020). Regulating in Pandemic: Evaluating Economic and Financial Policy Responses to the Coronavirus Crisis. Boston College Law School Legal Studies Research Paper, (527).

27. Harris, J., Depenbusch, L., Pal, A. A., Nair, R. M., \& Ramasamy, S. (2020). Food system disruption: initial livelihood and dietary effects of COVID-19 on vegetable producers in India. Food Security, 12(4), 841-851.

28. Hussain, S., Ahmad, A., Wajid, A., Khaliq, T., Hussain, N., Mubeen, M., Farid, H.U., Imran, M., Hammad, H.M., Awais, M., Ali, A., Aslam, M., Amin, A., Akram, R., Amanet, K. and Nasim. W. (2020a). Irrigation Scheduling for Cotton Cultivation. In Cotton Production and Uses (pp. 59-80). Springer, Singapore. https://doi.org/10.1007/978-981-15-1472-2_5.

29. Hussain, S., Mubeen, M., Ahmad, A., Akram, W., Hammad, H. M., Ali, M., Masood, N., Amin, A., Farid, H. U., Sultana, S. R. \& Fahad, S. (2020b). Using GIS tools to detect the land use/land cover changes during forty years in Lodhran District of Pakistan. Environmental Science and Pollution Research, 1, 1-17. https://doi.org/10.1007/s11356-019-06072-3.

30. Hussain, S., Mubeen, M., Akram, W., Ahmad, A., Habib-ur-Rahman, M., Ghaffar, A., Amin, A., Awais, M., Farid, H.U., Farooq, A. \& Nasim, W. (2020c). Study of land cover/land use changes using RS and GIS: a case study of Multan district, Pakistan. Environmental Monitoring and Assessment, 192(1), p.2. https://doi.org/10.1007/s10661-019-7959-1.

31. Hussain, S. and Karuppannan, S. (2021). Land use/land cover changes and their impact on land surface temperature using remote sensing technique in district Khanewal, Punjab Pakistan. Geology, Ecology, And Landscapes, 1-13. https://doi.org/10.1080/24749508.2021.1923272.

32. Imran, M. (2020). Online conference on impact of coronavirus on agri sector. The news. April 22, 2020 https://www.thenews.com.pk/print/647738-online-conference-on-impact-of-coronavirus-onagri-sector. 
33. Jamal, S. (2020). How will COVID-19 affect Pakistan farmers, food system? Gulf news Published: May 01, 2020. https://gulfnews.com/world/asia/pakistan/how-will-covid-19-affect-pakistan-farmersfood-system-1.71196910.

34. Kansiime, M. K., Tambo, J. A., Mugambi, M. I., Bundi, M. M., Kara, A., \& Owuor, M. C. (2020). COVID-19 implications on household income and food security in Kenya and Uganda: Findings from a rapid assessment. World Development, 105199.

35. Khaliq, M. A., Ali, S., Kamran, A., \& Qasrani, T. B. (2020). Opinion on Impact of Covid-19 Lockdown on Agriculture, Food Security and livelihoods in Pakistan.

36. Khan, N., Fahad, S., Naushad, M., \& Faisal, S. (2020a). COVID-2019 Locked down Impact on Dairy Industry in the World. Available at SSRN 3616325.

37. Khan, N., Fahad, S., Naushad, M., \& Faisal, S. (2020b). Effects of Social Stigma on the Sick People of Covid-2019 in the Community of the World. Available at SSRN 3600579.

38. Khan, N., Naushad, M., Akbar, A., Faisal, S., \& Fahad, S. (2020c). Critical review of COVID-2019 in Pakistan and its impact on Pakistan economy. Available at SSRN 3629718.

39. Khan, N., Naushad, M., Akbar, A., Faisal, S., \& Fahad, S. (2020d). Critical Review of COVID-2019 in Italy and Impact on Its Economy. Available at SSRN 3632007.

40. Kreutz, R., Algharably, E. A. E. H., Azizi, M., Dobrowolski, P., Guzik, T., Januszewicz, A., ... \& Burnier, M. (2020). Hypertension, the renin-angiotensin system, and the risk of lower respiratory tract infections and lung injury: implications for COVID-19European Society of Hypertension COVID-19 Task Force Review of Evidence. Cardiovascular Research.

41. Kumar, A., Padhee, A. K., \& Kumar, S. (2020). How Indian agriculture should change after COVID19. Food Security, 12(4), 837-840.

42. Lakhani, A. (2020). Which Melbourne metropolitan areas are vulnerable to COVID-19 based on age, disability and access to health services? Using spatial analysis to identify service gaps and inform delivery. Journal of Pain and Symptom Management. doi: 10.1016/j.jpainsymman.2020.03.041.

43. Latif, A. (2020). Pakistan to ease lockdown amid COVID-19. 05.05.2020. https://www.aa.com.tr/en/asia-pacific/pakistan-to-ease-lockdown-amid-covid-19/1829390.

44. Malik, K., Meki, M., Morduch, J., Ogden, T., Quinn, S., \& Said, F. (2020). COVID-19 and the Future of Microfinance: Evidence and Insights from Pakistan. Oxford Review of Economic Policy, Forthcoming.

45. Manzoor, M., Khan, I. A., \& Ahmad Mann, A. (2019). An investigation of the socio-cultural constraints in gender mainstreaming in food security at household level in rural punjab, pakistan. Journal of Agricultural Research (03681157), 57(2).

46. Mhlanga, D., \& Ndhlovu, E. (2020). Socio-economic Implications of the COVID-19 Pandemic on Smallholder Livelihoods in Zimbabwe.

47. Miller, M. (2020). 2019 Novel Coronavirus COVID-19 (2019-nCoV) Data Repository. BulletinAssociation of Canadian Map Libraries and Archives (ACMLA), (164), 47-51. 
48. Mollalo, A., Vahedi, B., \& Rivera, K. M. (2020). GIS-based spatial modeling of COVID-19 incidence rate in the continental United States. Science of The Total Environment, 138884.

https://doi.org/10.1016/j.scitotenv.2020.138884.

49. Mubeen, M., Bano, A., Ali, B., Islam, Z.U., Ahmad, A., Hussain, S., Fahad, S., \& Nasim, W. (2021). Effect of plant growth promoting bacteria and drought on spring maize (Zea mays L.). Pakistan Journal of Botant, 53(2). DOI: http://dx.doi.org/10.30848/PJB2021-2(38).

50. Murugesan, B., Karuppannan, S., Mengistie, A.T., Ranganathan, M., \& Gopalakrishnan, G. (2020) Distribution and Trend Analysis of COVID-19 in India: Geospatial Approach. Journal of Geographical Studies, 4(1), 1-9. https://dx.doi.org/10.21523/gcj5.20040101.

51. Niles, M. T., Bertmann, F., Morgan, E. H., Wentworth, T., Biehl, E., \& Neff, R. (2020). Food Access and Security During Coronavirus: A Vermont Study.

52. Pakistan bureau of statistics Government of Punjab. http://www.pbs.gov.pk/.

53. Pervaiz, B., Li, N., \& Manzoor, M. Q. (2019). AGRICULTURAL LAND USE AND FOOD SECURITY IN PAKISTAN: A STRUCTURAL EQUATION MODELING APPROACH. JOURNAL OF ANIMAL AND PLANT SCIENCES, 29(5), 1402-1412.

54. Rezaei, M., Nouri, A. A., Park, G. S., \& Kim, D. H. (2020). Application of Geographic Information System in Monitoring and Detecting the COVID-19 Outbreak. Iranian Journal of Public Health, 49, 114-116.

55. Richards, T. J., \& Rickard, B. (2020). COVID-19 impact on fruit and vegetable markets. Canadian Journal of Agricultural Economics/Revue canadienne d'agroeconomie.

56. Sabagh, A. E., Hossain, A., Islam, M. S., Iqbal, M. A., Fahad, S., Ratnasekera, D., \& Llanes, A. (2020). Consequences and Mitigation Strategies of Heat Stress for Sustainability of Soybean (Glycine max L. Merr.) Production under the Changing Climate. In Plant Stress Physiology. IntechOpen. http://dx.doi.org/10.5772/intechopen.92098.

57. Saha, A., Gupta, K., \& Patil, M. (2020). Monitoring and Epidemiological Trends of Coronavirus Disease (COVID-19) Around The World.

58. Sahoo, P. P., \& Rath, S. (2020). Potential Impact of Corona Virus on Agriculture Sector. Biotica Research Today, 2(4), 64-65.

59. Siche, R. (2020). What is the impact of COVID-19 disease on agriculture?. Scientia Agropecuaria, 11(1), 3-6.

60. Siddiqui, R., Samad, G., Nasir, M., \& Jalil, H. H. (2012). The impact of climate change on major agricultural crops: evidence from Punjab, Pakistan. The Pakistan Development Review, 261-274. DOI: 10.30541/v51i4llpp.261-276

61. Spinelli, A., \& Pellino, G. (2020). COVID-19 pandemic: perspectives on an unfolding crisis. Br J Surg, 10.

62. Stephens, E. C., Martin, G., van Wijk, M., Timsina, J., \& Snow, V. (2020). Impacts of COVID-19 on agricultural and food systems worldwide and on progress to the sustainable development 
63. Suleri, A.Q. (2020). Corona and the rural economy. The news. April 4, 2020. https://www.thenews.com.pk/print/638984-corona-and-the-rural-economy.

64. Sumner, A., Hoy, C., \& Ortiz-Juarez, E. (2020). Estimates of the Impact of COVID-19 on Global Poverty. UNU-WIDER, April, 800-9.

65. Sun, J., He, W. T., Wang, L., Lai, A., Ji, X., Zhai, X., \& Veit, M. (2020). COVID-19: epidemiology, evolution, and cross-disciplinary perspectives. Trends in Molecular Medicine.

66. WFP (world food program) (2020a). Global Report on Food Crises. 20 April 2020. https://www.wfp.org/publications/2020-global-report-food-crises.

67. WFP (world food program) (2020b). Global Report on Food Crises reveals scope of food crises as COVID-19 poses new risks to vulnerable countries. 21 April 2020. https://www.wfp.org/news/globalreport-food-crises-reveals-scope-food-crises-covid-19-poses-new-risks-vulnerable.

68. WHO (World Health Organization). (2020). Coronavirus disease 2019 (COVID-19): situation report, 72. WHO.

69. Wu, F., Zhao, S., Yu, B., Chen, Y.M., Wang, W., Song, Z.G., Hu, Y., Tao, Z.-W., Tian, J. H., Pei, Y-Y.,Yuan, M. L., Zhang, Y. L., Dai, F.-H., Liu, Y., Wang, Q.-M., Zheng, J.-J., Xu, L., Holmes, E. C. \& Zhang, Y.-Z. (2020). A new coronavirus associated with human respiratory disease in China. Nature. 579, 265269. DOI: https://doi.org/10.1038/s41586-020-2008-3.

70. Wu, T., Ge, X., Yu, G., \& Hu, E. (2020). Open-source analytics tools for studying the COVID-19 coronavirus outbreak. medRxiv.

71. Yih, W. K., Deshpande, S., Fuller, C., Heisey-Grove, D., Hsu, J., Kruskal, B. A., \& Puga, E. (2010). Evaluating real-time syndromic surveillance signals from ambulatory care data in four states. Public Health Reports, 125(1), 111-120.

72. Zahoor, S.A., Ahmad, S., Ahmad, A., Wajid, A., Khaliq, T., Mubeen, M., Hussain, S., Din, M.S.U., Amin, A., Awais, M. \& Nasim, W., (2019). Improving Water Use Efficiency in Agronomic Crop Production. In Agronomic Crops (pp. 13-29). Springer, Singapore. https://doi.org/10.1007/978-981-32-9783-8_2.

73. Zhang, F., \& Cao, N. (2019, July). Application and Research Progress of Geographic Information System (GIS) in Agriculture. In 2019 8th International Conference on Agro-Geoinformatics (AgroGeoinformatics) (pp. 1-5). IEEE.

74. Zhang, S., Wang, S., Yuan, L., Liu, X., \& Gong, B. (2020). The impact of epidemics on agricultural production and forecast of COVID-19. China Agricultural Economic Review.

75. Zhou, C., Su, F., Pei, T., Zhang, A., Du, Y., Luo, B. \& Song, C. (2020). COVID-19: challenges to GIS with big data. Geography and Sustainability.

76. Zhu, N., Zhang, D., Wang, W., Li, X., Yang, B., Song, J., Zhao, X., Huang, B.,Shi, W., Lu, R., Niu, P., Zhan, F., Ma, X., Wang, D., Xu, W., Wu, G., Gao, G. F. \& Tan, W. (2020). A novel coronavirus from patients with pneumonia in China, 2019. The New England Journal of Medicine, 382(8), 727-33. DOI: https://doi.org/10.1056/NEJMoa2001017. 


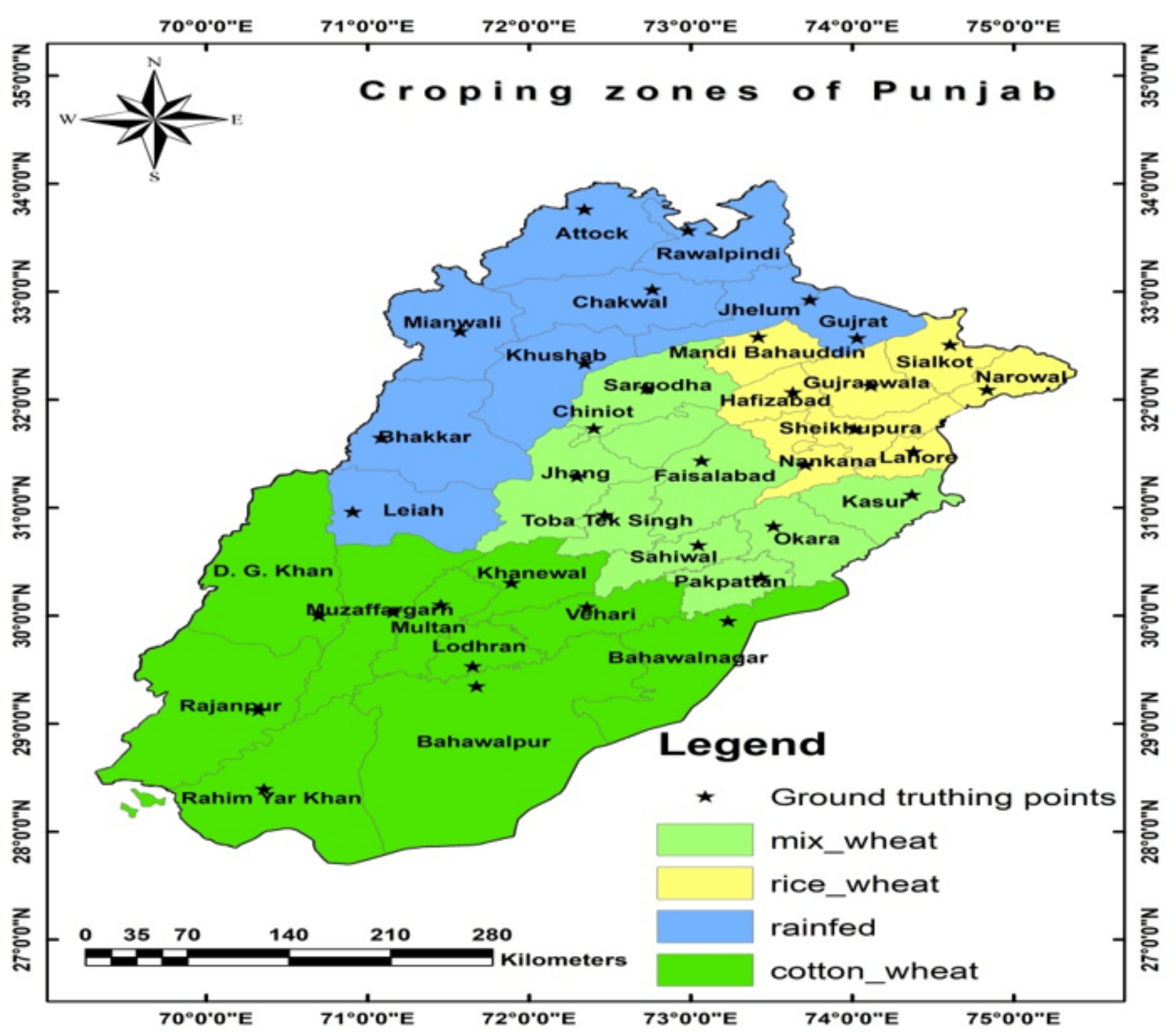

Figure 1

Study area map of Punjab 


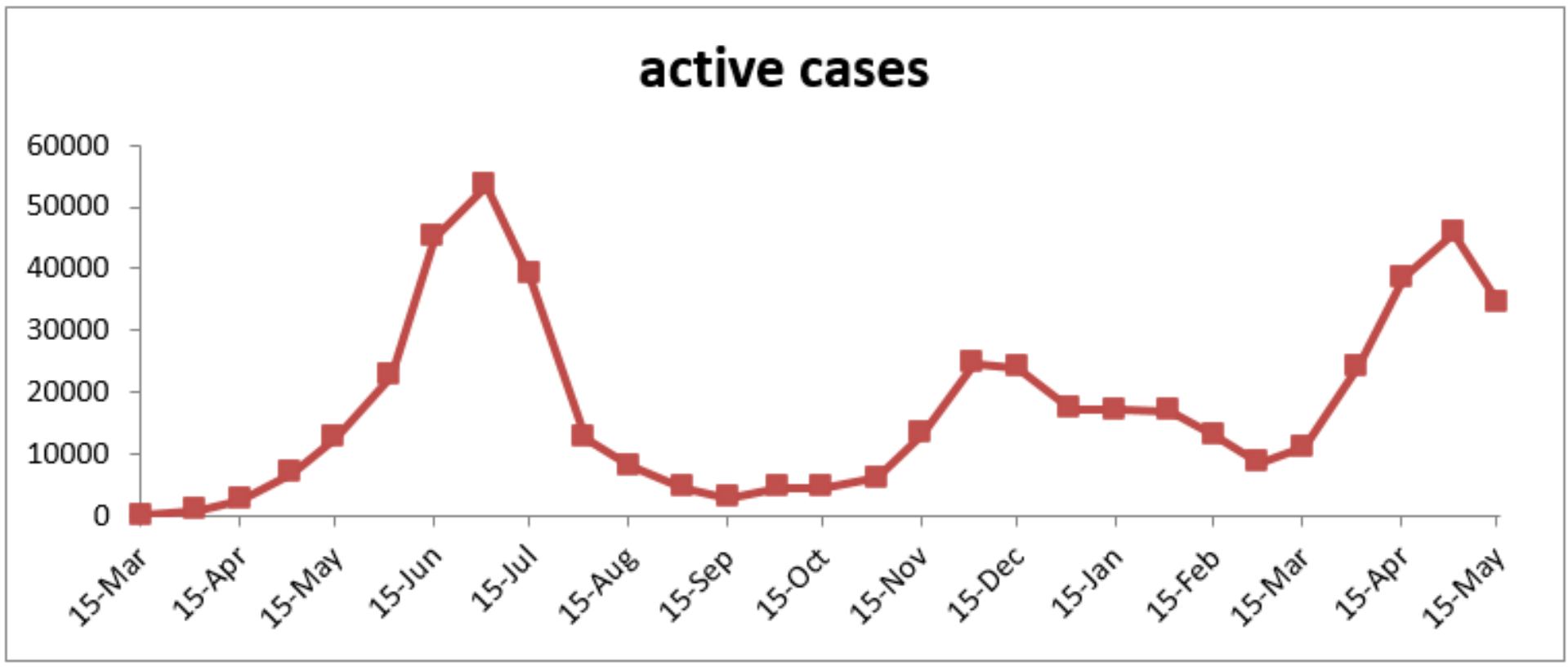

Figure 2

Trend of COVID-19 in Punjab, Pakistan 


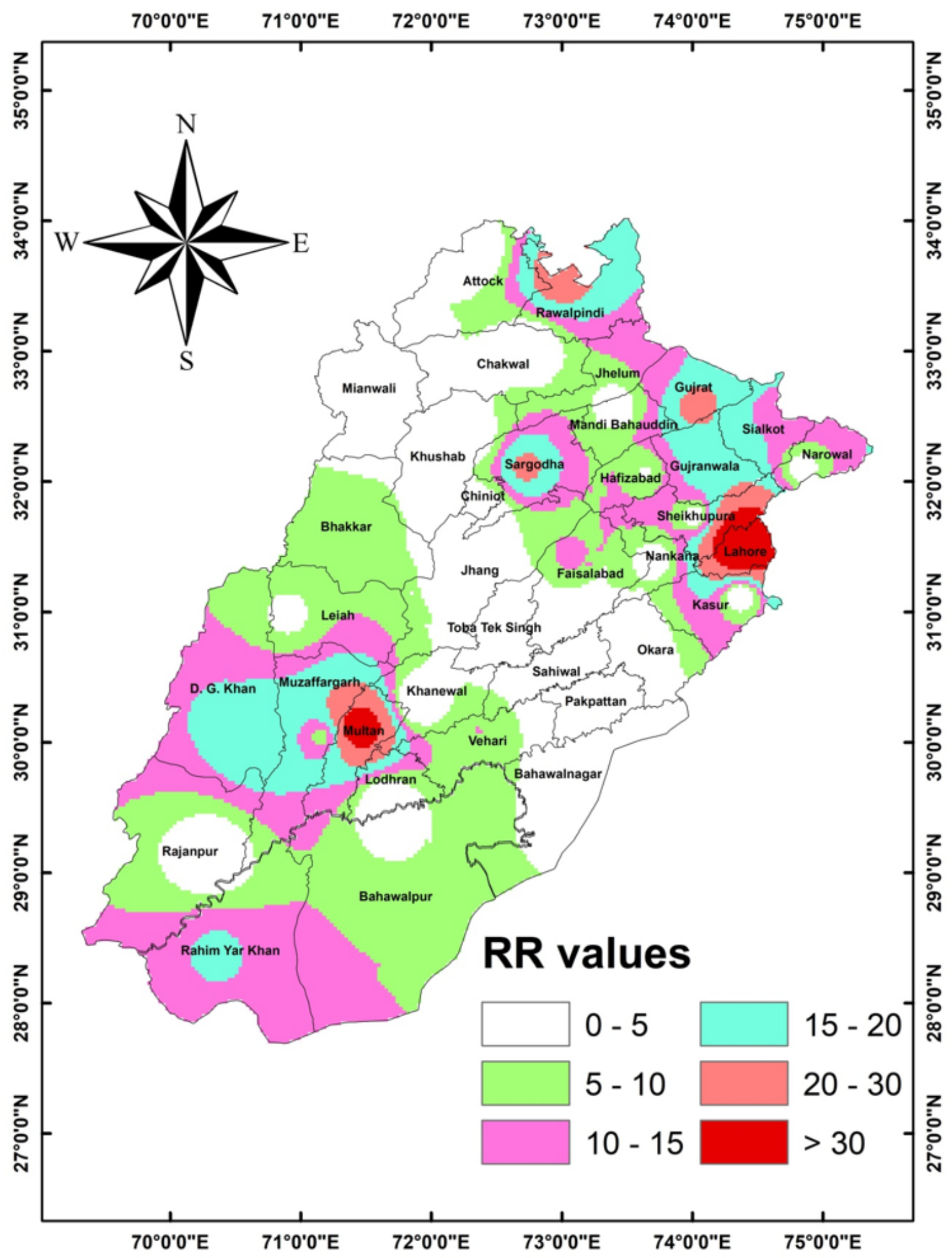

Figure 3

Mean of Relative Risk (RR) values of COVID-19 using STSS during 15th March to 15th November 2020 in different districts of Punjab 


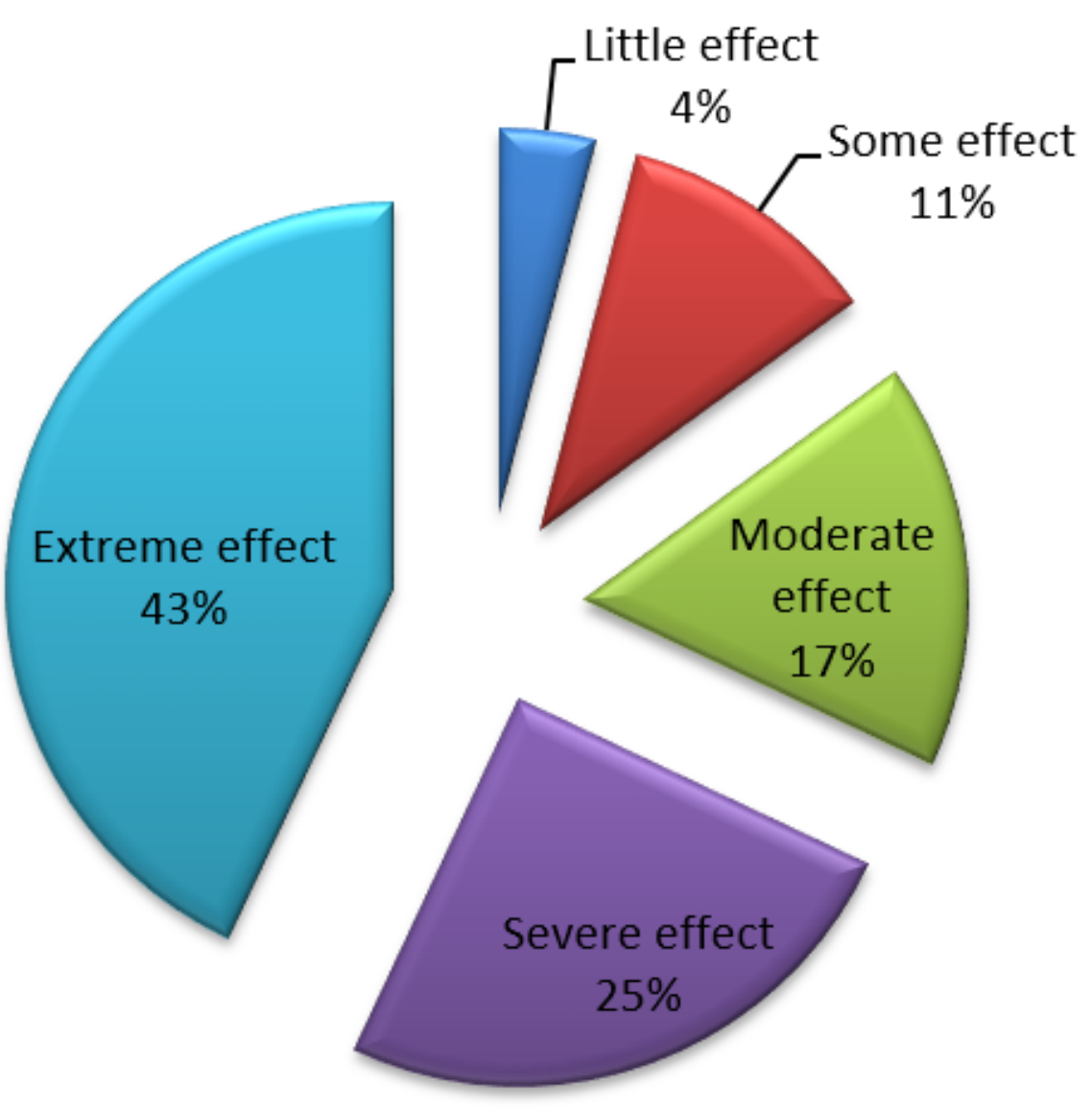

Figure 4

Response of farmers about agriculture during COVID-19 in Punjab 


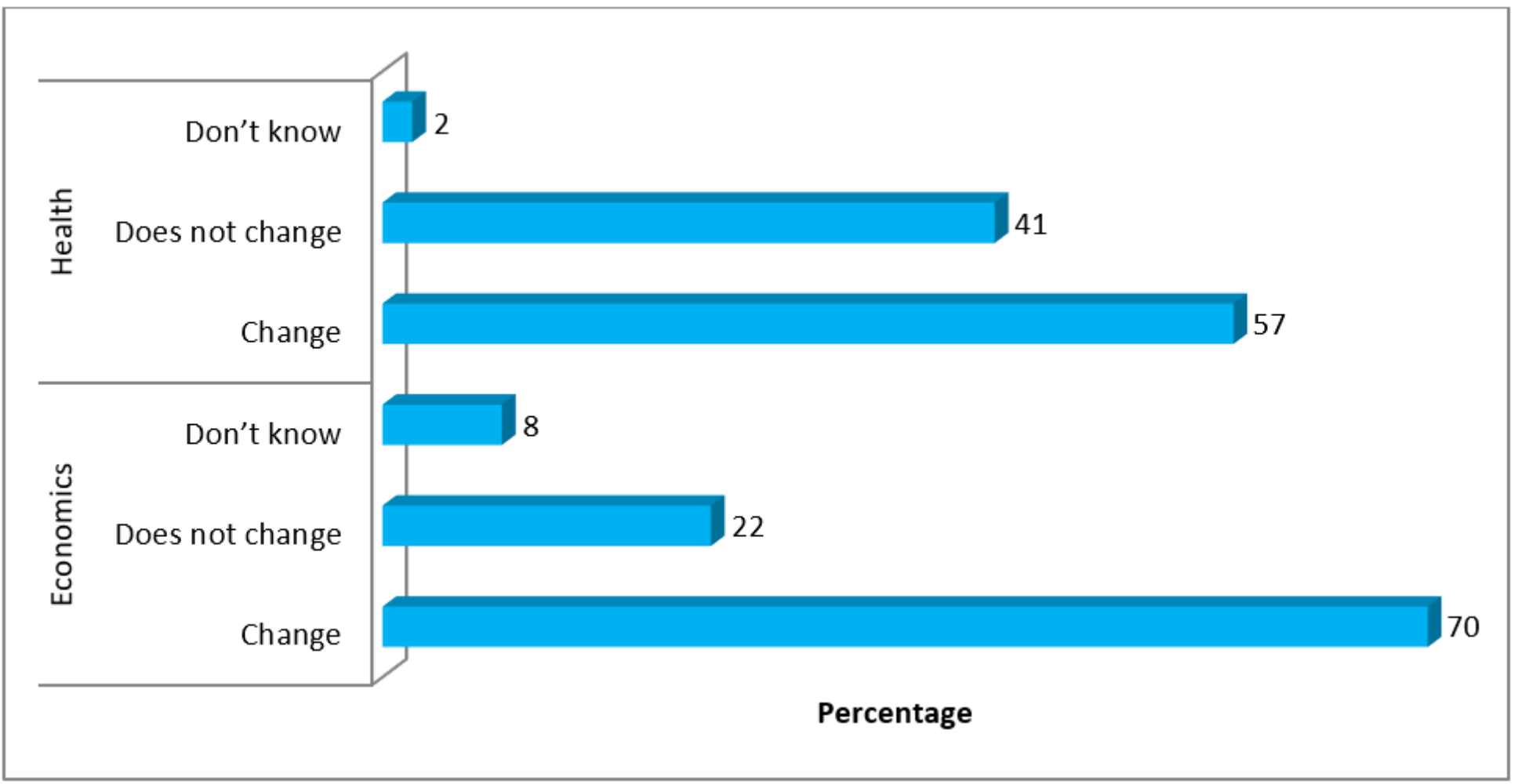

Figure 5

Farmer response about health and economics during lockdown in Punjab

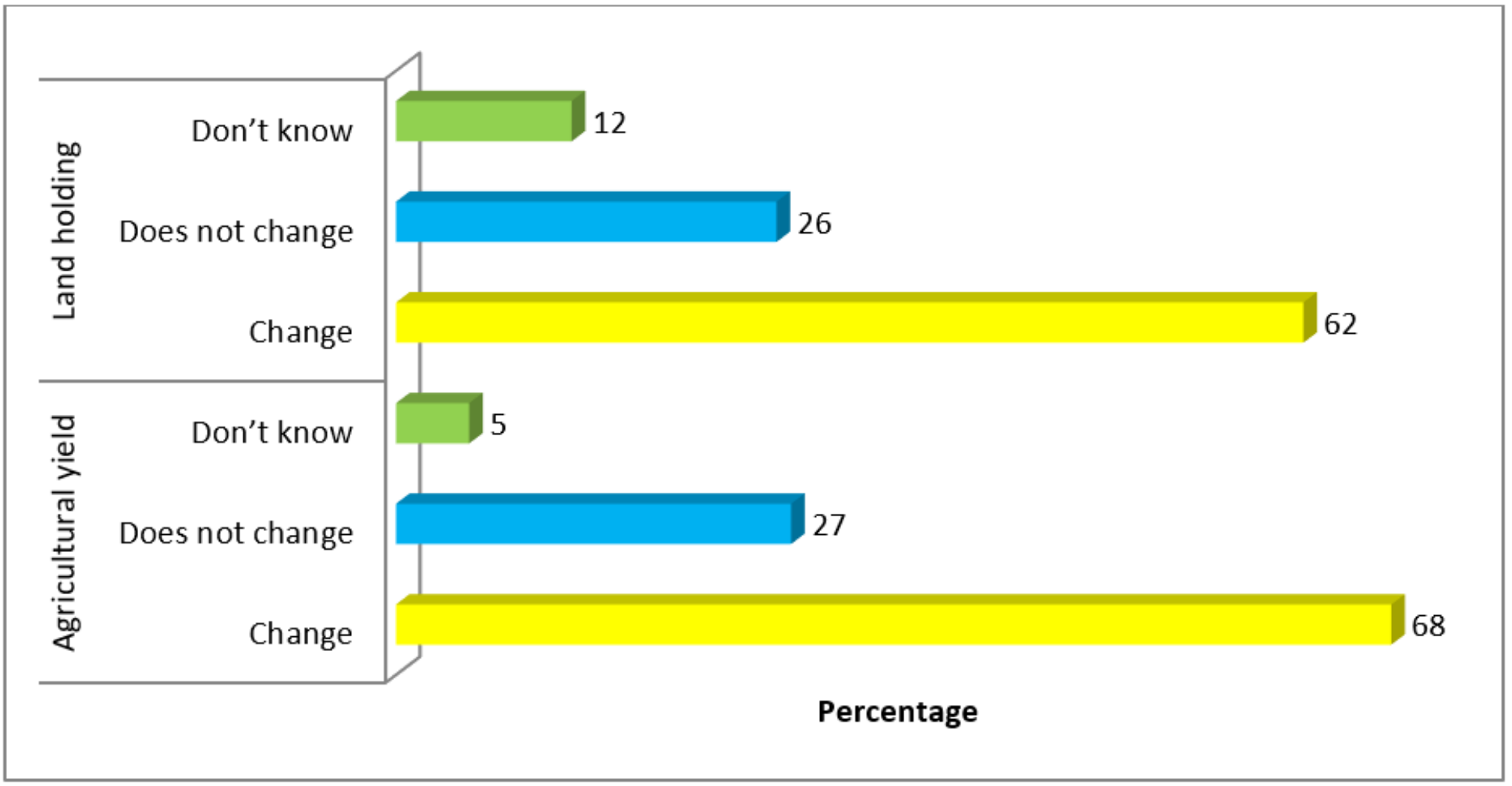

\section{Figure 6}

Recnnnce of farmerc ahnut land holdinn and agriculture yield during COVID-19 in Punjab Loading [MathJax]/jax/output/CommonHTML/jax.js 


\section{Milk Vegetatble and furits $\square$ Wheat}

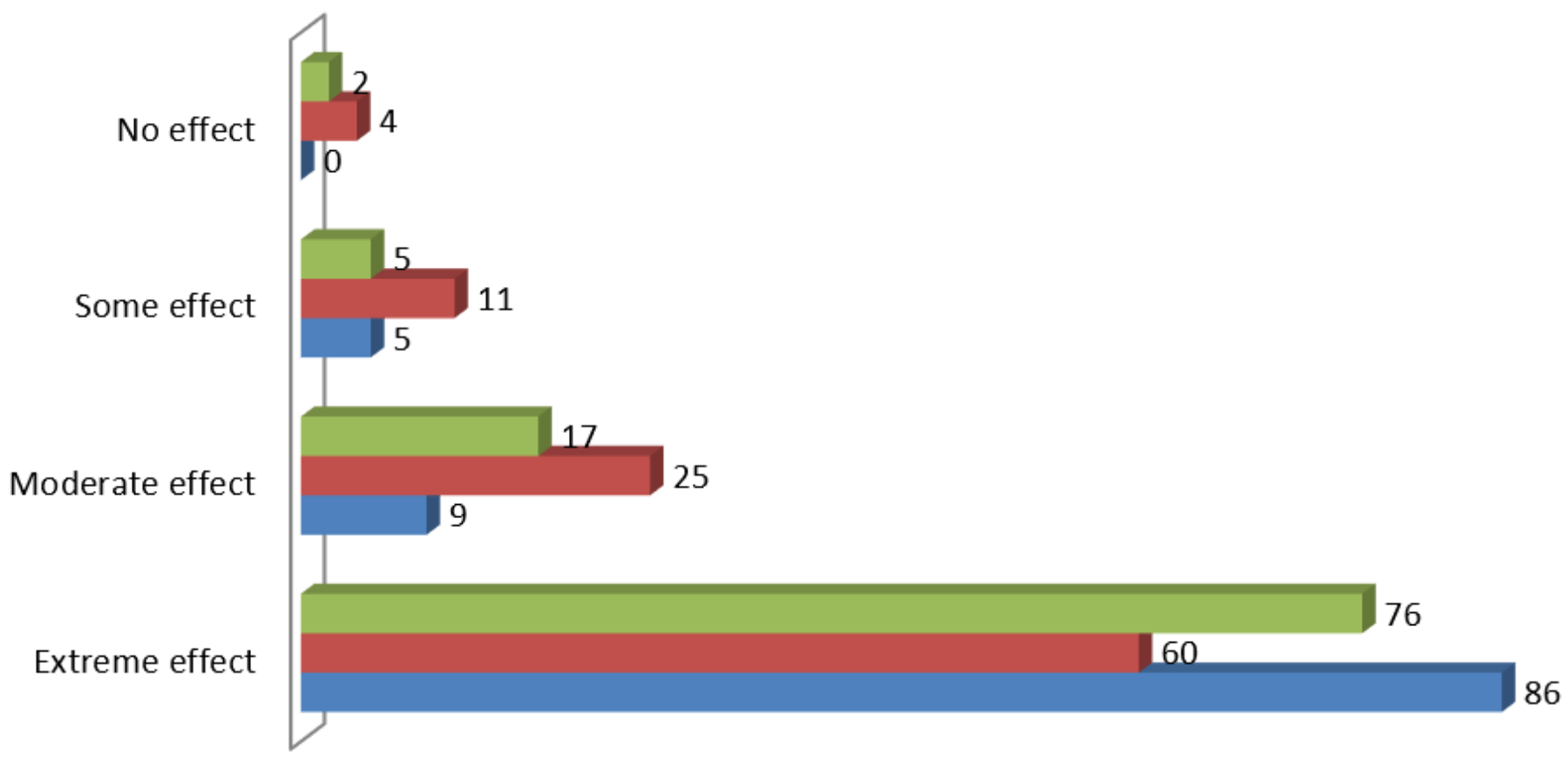

\section{Figure 7}

Effect of COVID-10 on various crops and milk during COVID-19 in Punjab

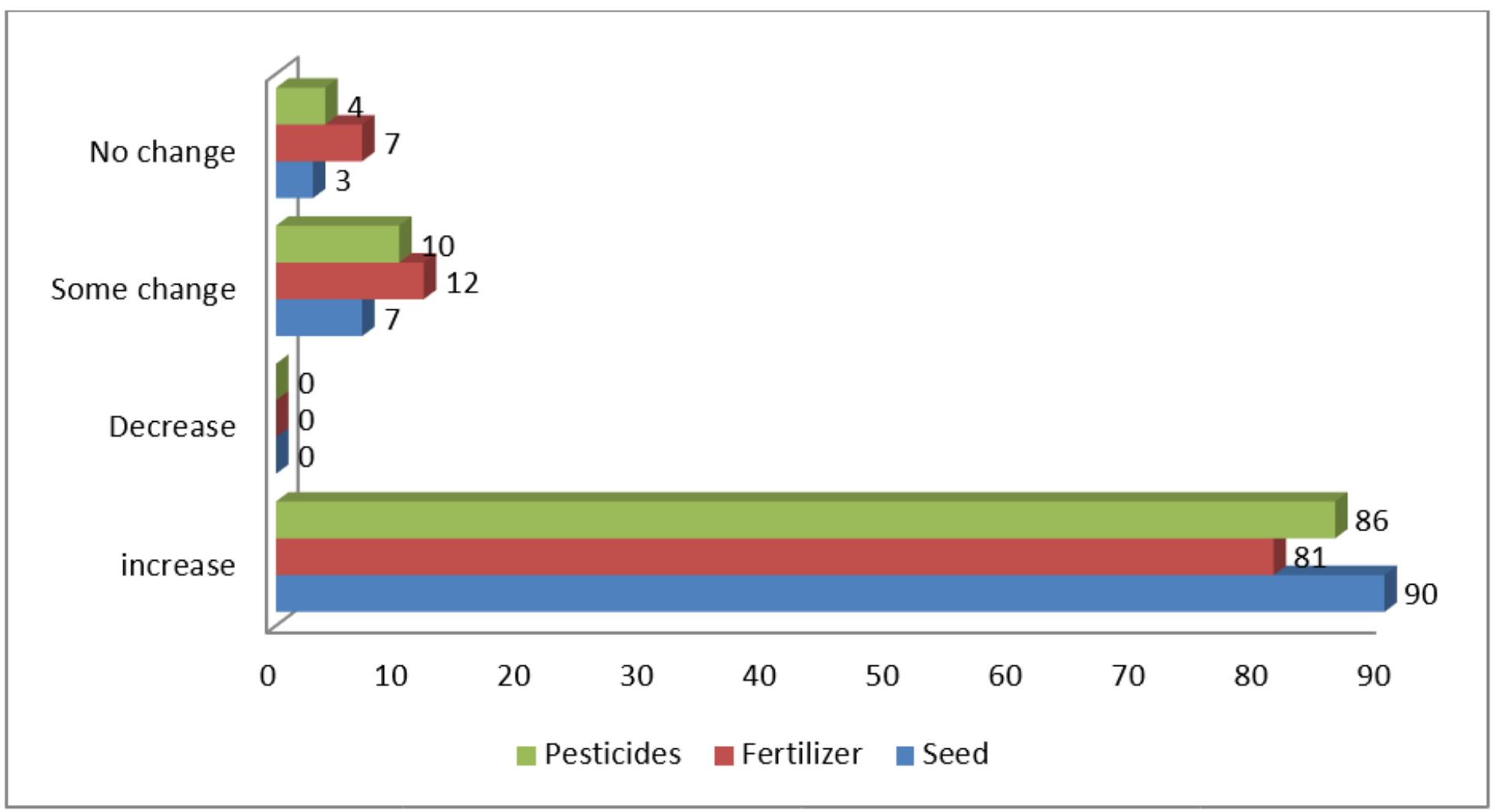

\section{Fiaure 8}


Attributed Farm Input Price during COVID-19 in Punjab

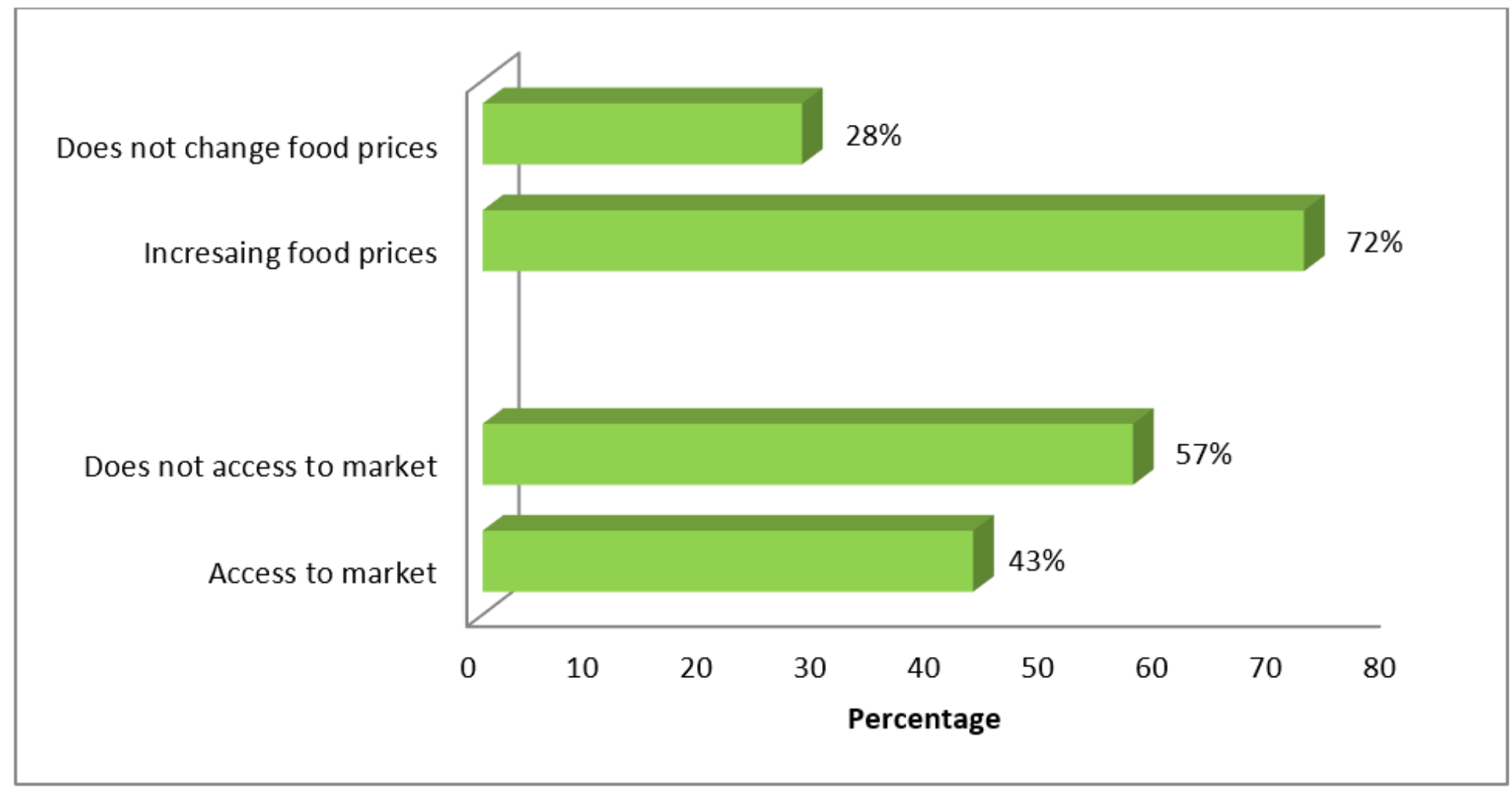

Figure 9

Response of farmers about food prices and access to market during COVID-19 in Punjab 